\title{
Sylvian aqueduct syndrome as a sign of acute obstructive hydrocephalus in children
}

\author{
AMRIK S. CHATTHA AND G. ROBERT DELONG \\ From the Department of Neurology, Massachusetts General Hospital, \\ Boston, Massachusetts 02114, U.S.A.
}

SYNOPSIS Eight cases of obstructive hydrocephalus manifesting palsy of upward gaze and other features of the Sylvian aqueduct syndrome are reported. During the crisis of intracranial hyper- $\$$ tension, all of them developed upward gaze palsy and variable abnormalities of the convergence $\vec{\circ}$ mechanism such as paralysis, spasm, and convergence nystagmus. The frequent apparent blindness $-\vec{J}$ was probably related to gaze paralysis, since visual evoked responses were present. All these ocular $\vec{\sigma}_{\mathscr{O}}$ abnormalities disappeared after shunting. Periaqueductal dysfunction on the basis of raised intra- $\overline{3}$ cranial pressure is postulated as the possible mechanism for the above ocular manifestations. The $\frac{7}{0}$ 'setting sun' sign is frequently seen in infants and children with hydrocephalus and has been con- $\mathscr{\infty}_{\infty}$ sidered in the past to result from displacement of eyeballs by pressure from the orbital roof plate $\omega$ Our observations would suggest periaqueductal dysfunction rather than the mechanical displace $\mathbb{C}_{\infty}^{\infty}$ ment as the possible mechanism for this sign.

Impairment of upward gaze is a well known neurological sign of diseases which affect the basal ganglia, mesencephalon, and the fourth ventricle (Cogan, 1956). The exact clinical localization is assisted by the accompanying features. When the paralysis of upward gaze is combined with abnormalities of the pupil, paralysis or spasm of convergence and nystagmus retractorius, a periaqueductal localization is indicated and this constellation of findings is called the Koerber-Salus-Elschnig Sylvian aqueduct syndrome (Kestenbaum, 1946). Paralysis of upward gaze alone is commonly called Parinaud's syndrome, though some authors (Walsh and Hoyt, 1969) use Parinaud's synonymously with the Sylvian aqueduct syndrome. The partial or complete Sylvian aqueduct syndrome has been recorded in patients with pinealoma, vascular lesions, encephalitis, trauma, multiple sclerosis, neurosyphilis (Cogan, 1956), and on a congenital basis (Fredericks and Van Nuis, 1967). The paralysis of upward gaze has also been reported in association with raised intracranial pressure (Schwarz and Rosner, 1941), particularly in hydrocephalus. Pennybacker (1940) first reported five patients of adult onset hydrocephalus due to Accepted 5 July 1974.) aqueductal stenosis who had paralysis of urs ward gaze and pupillary abnormalities. Subse quently, there have been isolated case reports $\overrightarrow{0}$ upward gaze paralysis occurring in hydr cephalus, mostly of later onset (Globus and Bergman, 1946; case 1; Beckett et al., 1950, case $\sum_{\Sigma}^{\circ}$ 8; Cassinari et al., 1963; Nag and Falconer, 1966, case 8; Lerner et al., 1969; Jerva and Nelson, 1971; Shallat et al., 1973; and Swash, $\stackrel{\mathbb{\perp}}{\unrhd}$ 1974); however, this reported association has not $\overrightarrow{\vec{B}}$ found its way into the leading textbooks of $\frac{\circ}{3}$ neuro-ophthalmology of Kestenbaum (1946), Cogan (1956), and Walsh and Hoyt (1969) and the review articles of Holmes (1921), Smith et al., (1959), Segarra and Ojeman (1961), and Hatchero and Klintworth (1966).

The purpose of the present communication is to report the presence, in association with acute hydrocephalus in children, of a continuum of

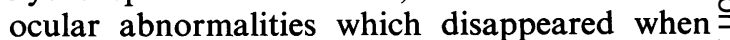
the pressure was lowered by shunting procedures. Subsequent follow-up in these cases did not reveal any evidence of mass lesion. The mode of $\sigma$ presentation and neuro-ophthalmological ob- $N$ servations of cases 2 and 3 in this series are $\underset{\omega}{N}$ reported below. 
CASE 2

M.E., a white, male infant, was admitted to the Massachusetts General Hospital on 3 October 1968, for the first time for increasing lethargy, irritability, and vomiting of five days' duration. He was born of a full-term normal pregnancy and was delivered by Caesarean section with a birth weight of $3.6 \mathrm{~kg}$ ( $7 \mathrm{lb} 15 \mathrm{oz}$ ). The early neonatal period was unremarkable.

Examination on admission revealed an irritable male child with a head circumference of $45 \mathrm{~cm}$ (97th percentile). The anterior fontanelle measured $5 \times 5$ $\mathrm{cm}$ and was tense and bulging. Transillumination of the skull was negative. The chest, cardiovascular system, and abdomen were normal. The child was lethargic and irritable and had a high pitched cry. He could not sit and had poor head control. Visual fixation and following were absent and there was no blink to visual threat. The disc margins of optic fundi were blurred and venous pulsations were poor. Both eyes were directed downwards ('setting sun' sign). The lateral gaze was normal to the left side. There was inturning of the right eye and limitation of abduction. Opticokinetic nystagmus could not be elicited. The other cranial nerves were normal. The child moved all the extremities well. The deep tendon reflexes were bilaterally brisk and the plantar responses were extensor.

It was concluded that the child had high intracranial pressure. He was put on intravenous mannitol and steroid therapy and lumbar puncture was done carefully, which revealed an opening pressure of $330 \mathrm{mmH}_{2} \mathrm{O}$. The closing pressure was 200 $\mathrm{mmH}_{2} \mathrm{O}$. There were 65 erythrocytes and no white cells in $1 \mathrm{~mm}^{3}$ of cerebrospinal fluid (CSF). The CSF protein content was $48 \mathrm{mg}$ and sugar $58 \mathrm{mg} /$ dl. The other laboratory investigations, including blood sugar, blood urea nitrogen, $\mathrm{Na}, \mathrm{K}, \mathrm{Cl}$, and serum protein levels were normal.

The skull radiographs were suggestive of diastasis of sutures. The pneumoencephalogram revealed dilatation of both lateral ventricles, the 3rd and the 4th ventricle. The cisterna magna was large. Most of the air remained trapped in the infratentorial compartment suggesting communicating hydrocephalus.

A ventriculoatrial shunt was installed on 16 October 1968. The anterior fontanelle became flat after the shunt and the child appeared more alert but still did not fix or follow visually and a question of blindness was raised.

The neuro-ophthalmological examination revealed normal extraocular movements on lateral gaze, but paralysis of vertical gaze. The pupils were 4-5 mm, equal, and reacting to light. Some degree of opticokinetic nystagmus was present when the drum was moved from right to left, suggesting that the child could probably see. Visual evoked responses done the next day were normal. At this time the child began to recognize his parents and thereafter could fix and follow well, and the 'setting sun' sign had disappeared. He was sent home.

The child was admitted again to the Massachusetts General Hospital on 8 November 1969, with the history of vomiting of two days' duration and lethargy. The anterior fontanelle was full. Under observation he was intermittently irritable and unresponsive. The pupils now were $4-5 \mathrm{~mm}$, equal, and sluggish in reacting to light. The extraocular movements, on oculocephalic reflex, were full on lateral and downward gaze but no upward movement could be elicited. Blockage of the shunt was considered responsible for the clinical state and shunt revision was done on 9 November 1968. The ventricular fluid pressure at the time of shunting was $240 \mathrm{~mm}$ CSF. The sensorium and extraocular movements improved after the shunt revision but on 19 November 1968 the child again became more lethargic and started vomiting.

The fundus examination revealed flame-shaped haemorrhages on both sides. The child was again observed to have paralysis of upward gaze and weakness of the right lateral rectus muscle. He lacked visual fixation and following and there was no blink to visual threat. The chest radiograph revealed displacement of the distal end of the shunt and replacement was considered. The ventricular pressure at the time of shunting was more than $600 \mathrm{mmH}_{2} \mathrm{O}$ and CSF was haemorrhagic. The child showed initial improvement for a short time but again became lethargic, refused to eat, and started vomiting. On 23 November 1968 a shunt revision was done for the third time and revealed occlusion of the ventricular end by fibrinous material. Even after the revision, the shunt was not functioning very well. There were intermittent periods of raised pressure for which frequent lumbar punctures were done revealing high CSF pressures. The CSF contained 2,300 WBCs per $\mathrm{mm}^{3}$, the majority being polymorphonuclear cells. The CSF sugar content was $25 \mathrm{mg}$, proteins $73 \mathrm{mg} /$ $\mathrm{dl}$, and the child was treated with antibiotics for meningitis. The CSF cultures were negative.

A neuro-ophthalmological examination on 11 December 1968, revealed that the child did not respond to light or visual threat. He moved his eyes from side to side, but not upwards. Lid retraction was present, as was Bell's phenomenon. The right pupil was $5 \mathrm{~mm}$ with sluggish reaction to light. The left pupil was $6 \mathrm{~mm}$ with no reaction to light. Both optic discs looked pale, the left showing more pallor than the right. Opticokinetic nystagmus was absent. There was frequent, quick, episodic divergence of 

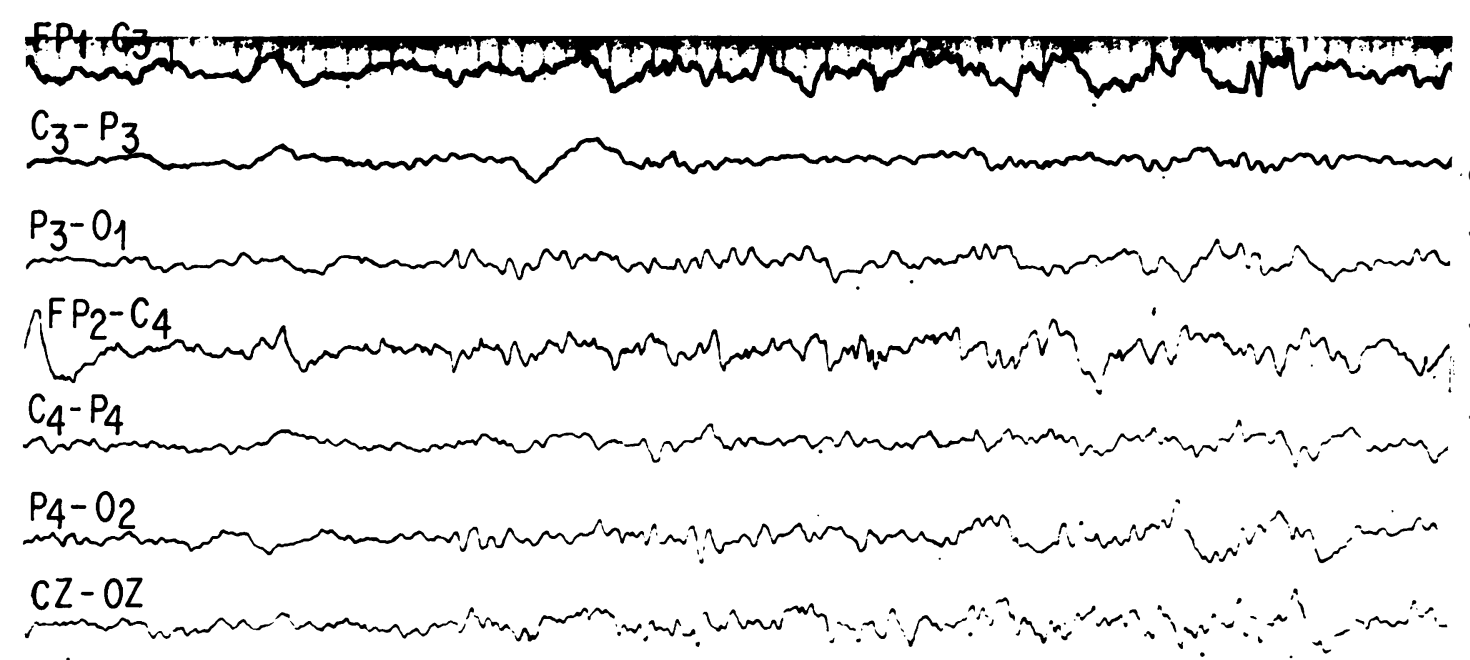

STROBE

FIG. 1. Case 4. Electroencephalogram showing evoked response to photic stimulation.

the eyes, which would come back slowly to the primary position, without any convergence nystagmus.

The electroencephalogram (EEG) revealed irregular 2-3 $\mathrm{Hz}$ slowing on both sides posteriorly with frequent $1-2 \mathrm{~Hz}$ high voltage rhythmic bursts. Photic driving was present. The child gradually improved with frequent lumbar punctures and antibiotic therapy. All the above ocular abnormalities disappeared in one week.

The next episode of blockage of the shunt occurred at the age of 9 months and was again accompanied by absence of following, fixation, and opticokinetic nystagmus.

The child was last seen at the age of 2 years, when the shunt tube was lengthened. The child was alert and could follow objects and pick up toys. The extraocular movements were intact and pupillary responses were normal.

COMMENT This child had communicating hydrocephalus. The posterior fossa had a large cisterna magna or a cyst. He had four episodes of shunt obstruction all accompanied by ocular manifestations characterized by the paralysis of upward gaze, dilated, poorly reacting pupils, and absence of fixation and following responses. There was repeated weakness of the right lateral rectus muscle and one episode of divergence nystagmus with paralysis of upward gaze. Oculat abnormalities disappeared after shunting.

CASE 3

L.R. was a 1 week old Portuguese female child wha was first admitted to the Massachusetts Gener of Hospital in April 1968 for neonatal seizures due to $E$. coli meningitis. She was born to a 21 year old mother who had hypertension during pregnancy. The child was delivered by mid-forceps and suffered left lower facial paralysis as a consequence; the latter disappeared in one week. The child's birth weight was $3.1 \mathrm{~kg}(6 \mathrm{lb} 13 \mathrm{oz})$ and head circumference was $35 \mathrm{~cm}$. The lumbar puncture at that time revealed blood in the CSF. The cultures of urine, blood, and CSF grew E. coli and she was treated with ampicillin. Because seizures had occurred she was given phenobarbitone $7.5 \mathrm{mg}$ twice daily and phenytoin $5 \mathrm{mg}$ three times daily. When discharged after 12 days she was free of seizures.

The child was admitted a second time to the Massachusetts General Hospital at the age of 10 weeks for evaluation of increasing head size. The $\frac{9}{3}$ head circumference was $42 \mathrm{~cm}$ (97th percentile) and a $>$ 'cracked pot' sound was present on percussion. There was mild head transillumination. The lumbar $N$ puncture revealed an opening pressure of $200^{\circ}$ $\mathrm{mmH}_{2} \mathrm{O}$. The $\mathrm{CSF}$ protein was $150 \mathrm{mg}$ and sugar $30 \mathrm{mg} / \mathrm{dl}$. The eyes were abnormal in that they 

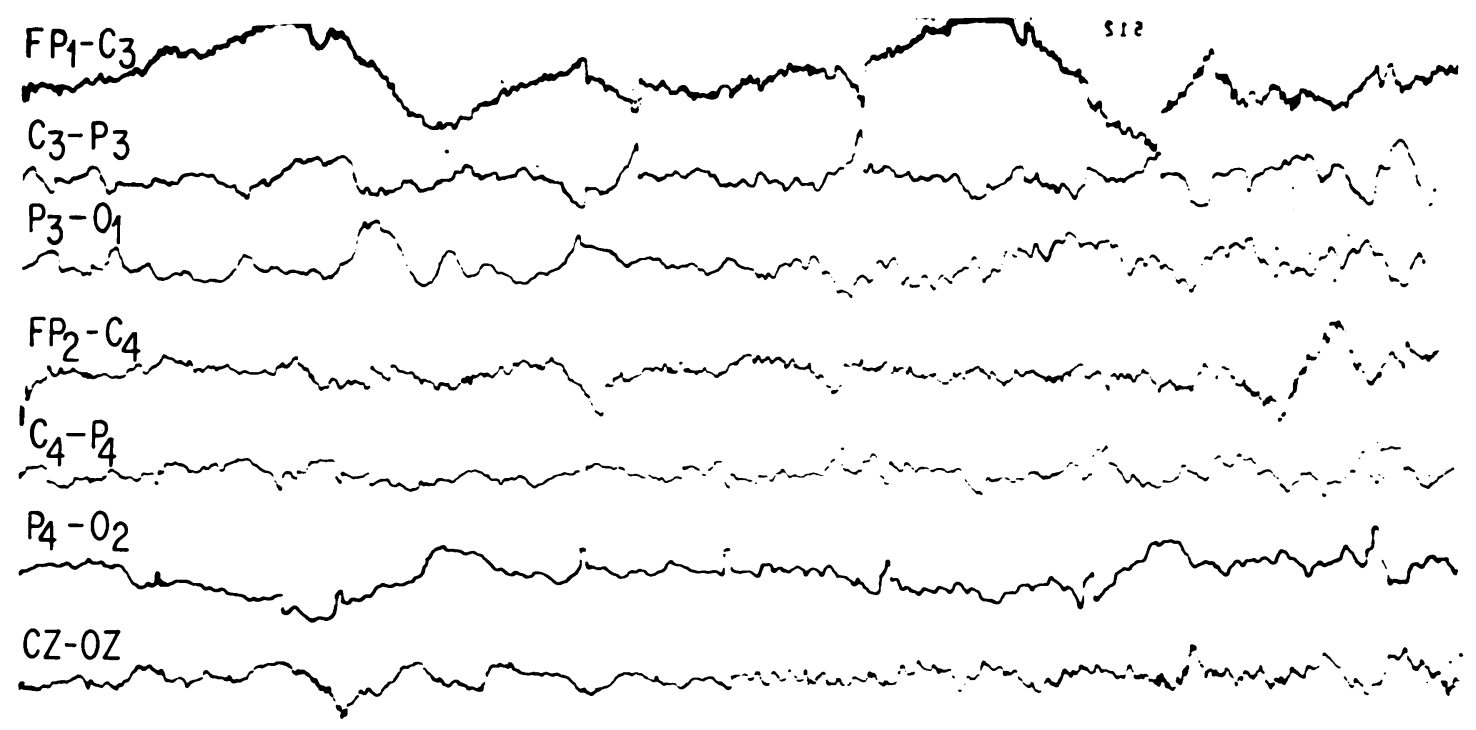

STROBE

FIG. 2. Case 5. Electroencephalogram showing the presence of evoked response to photic stimulation.

were directed straight ahead and vertical movements were nearly absent. In contrast, the lateral movements were intact. The pupils were $6 \mathrm{~mm}$ and sluggishly reacting. The fundi were normal. The limbs moved normally and the deep tendon reflexes were brisk but the plantar responses were extensor.

A pneumoencephalogram revealed aqueductal stenosis and possibly post-meningitic communicating hydrocephalus. A ventriculoatrial shunt was done on 2 May 1968. Thereafter she enjoyed good health and continued to develop but was somewhat slow for her age. There were no abnormal neurological findings and extraocular movements were intact.

She was admitted to the Massachusetts General Hospital again in October 1970, at the age of 2 years 9 months, for irritability of three days' duration and a draining sinus in the neck near the shunt catheter. At that time the neurological examination revealed her to be less alert and irritable. The head circumference was $48 \mathrm{~cm}$. The fundi were normal and the extraocular movements were intact. The pupils were $4 \mathrm{~mm}$ equal and reactive. The other cranial nerves were normal. The patient moved all the extremities well. The deep tendon reflexes were brisk, equal, and symmetrical. The coordination was normal and the sensations were intact. The plantar responses were bilaterally upgoing. The lumbar puncture revealed an opening pressure of $150 \mathrm{mmH}_{2} \mathrm{O}$ and the $\mathrm{CSF}$ was slightly xanthochromic. There were 2 lymphocytes and 10 erythrocytes per $\mathrm{mm}^{3}$. The protein content was $110 \mathrm{mg}$ and sugar $60 \mathrm{mg} / \mathrm{dl}$. The CSF culture revealed no growth. The urine culture grew Gram negative rods and the blood culture grew Staphylococcus aureus and Clostridia perfringens. The skull radiographs and electrolytes were normal. It was decided that the shunt was infected so it was removed on 9 October 1970, and intravenous oxacillin $400 \mathrm{mg}$ every four hours was started.

On 13 October 1970, some leakage from the scalp was noted and the child appeared less alert. Lumbar puncture was done and revealed an opening pressure of $200 \mathrm{mmCSF}$ with good relaxation. The protein content was $58 \mathrm{mg} / \mathrm{dl}$ and sugar was $64 \mathrm{mg} / \mathrm{dl}$. There were five red cells and two polymorphonuclear cells per $\mathrm{mm}^{3}$. The next day the child became less alert and was lethargic. The pupils were $4 \mathrm{~mm}$ and equal, but reacted sluggishly to light. The venous pulsations of the optic fundi were reduced. The cranial nerves were normal. There was bilateral ankle clonus with extensor plantar reflexes. In the following hours she gradually became more obtunded. Repeat lumbar puncture revealed an opening pressure of $180 \mathrm{mmCSF}$ without any cellular response. The lateral movements were normal to the doll's manoeuvre, but no upward movements could be elicited. The electroencephalogram revealed diffuse $2-3 \mathrm{~Hz}$ arrhythmic polymorphic slowing bilaterally mixed with 4-5 $\mathrm{Hz}$ rhythmic theta waves. 
The slowing was more prominent posteriorly and slight reaction to photic stimulation was present.

It was concluded that the child had high intracranial pressure, hence a right frontal burr hole was done on the same day and emergency ventricular drainage was done with Scott's cannula. The CSF drained with a gush under very high pressure. A pneumoencephalogram done the next day demonstrated dilated lateral and third ventricles. The child became more alert but still did not follow and fixate well. She had a blank stare with retraction of upper lids. The pupils were $6 \mathrm{~mm}$, equal and reacted sluggishly. The fundus examination revealed sharp disc margins.

On 23 October 1970, the visual acuity was adequate for seeing small objects and she was able to turn the eyes laterally and downwards but not upwards. She did not converge. The pupils were $6 \mathrm{~mm}$ each and sluggish in reaction. Opticokinetic nystagmus was normal horizontally. There were slow oscillations with the drum moving upwards but retraction nystagmus occurred when the drum was moved downwards. Bell's phenomenon was present. These findings were considered consistent with lesions in the periaqueductal grey matter of the upper midbrain.

The child gradually improved. Ventriculoperi- toneal shunt was later done. The ocular abnormalities gradually disappeared in about a week.

COMMENT This child had two episodes of raised intracranial pressure on the basis of aqueductal stenosis. In both episodes, there was paralysis of upward gaze. The second episode was characterized by all the features of the Sylvian aqueduct syndrome. She also had blank stare with no fixing and following responses. These abnormalities disappeared after shunting.

\section{DISCUSSION}

These eight patients presented various degrees of ocular disorder ranging from simple paresis of upward gaze to the complete syndrome of the Sylvian aqueduct (Tables 1 and 2). The paresis of upward gaze was the common feature in all cases and the abnormalities of pupil and convergence mechanism were superimposed. Two patients (cases 1 and 6) had spasm of convergence along with upward gaze paralysis. A similar ocularo i abnormality has been described by Fisher (1967) $)_{\infty}^{\infty}$ in patients with thalamic haemorrhage where the्षे 을

TABLE 1

CLINICAL FINDINGS IN EIGHT PATIENTS

\begin{tabular}{|c|c|c|c|c|c|c|c|c|c|c|}
\hline No. & Name & Age & Sex & $\begin{array}{c}\text { Aetiology of raised } \\
\qquad I C P^{*}\end{array}$ & $\begin{array}{c}\mathrm{CSF} \\
\text { pressure } \\
\left(\mathrm{mm} \mathrm{H}_{2} \mathrm{O}\right)\end{array}$ & $\begin{array}{l}\text { Upward } \\
\text { gaze } \\
\text { palsy }\end{array}$ & Convergence & $\begin{array}{l}\text { Lid } \\
\text { retrac- } \\
\text { tion }\end{array}$ & $\begin{array}{l}\text { Nystag- } \\
\text { mus } \\
\text { retrac- } \\
\text { torius }\end{array}$ & $\begin{array}{l}\text { Doll's head } \\
\text { manoeuvre }\end{array}$ \\
\hline 1 & L.F. & 7 wk & $\mathbf{F}$ & Posterior fossa cyst & 340 & + & $\begin{array}{l}\text { Spasm (eyes } \\
\text { maintained in } \\
\text { and down) }\end{array}$ & + & 一 & No response \\
\hline 2 & M.E. & $5 \mathrm{mo}$. & $\mathbf{M}$ & $\begin{array}{l}\text { Large cisterna } \\
\text { magna, posterior } \\
\text { fossa cyst? }\end{array}$ & $\begin{array}{l}600 \text { at ven- } \\
\text { tricular tap }\end{array}$ & + & $\begin{array}{l}\text { Episodic diverg- } \\
\text { ence move- } \\
\text { ments }\end{array}$ & + & - & No response \\
\hline 3 & L.R. & $29 / 12 \mathrm{yr}$ & $\mathbf{F}$ & $\begin{array}{l}\text { Post-meningitic } \\
\text { hydrocephalus; } \\
\text { aqueductal } \\
\text { stenosis }\end{array}$ & $\begin{array}{l}180 \text { at } \mathbf{L . P .} \\
\text { and very } \\
\text { high at ven- } \\
\text { tricular tap }\end{array}$ & + & Absent & + & + & $\begin{array}{l}\text { Lateral and } \\
\text { down gaze } \\
\text { present }\end{array}$ \\
\hline 4 & M.D. & $16 \mathrm{yr}$ & $\mathbf{F}$ & $\begin{array}{l}\text { Aqueductal stenosis } \\
\text { post-op. subdural } \\
\text { haematoma }\end{array}$ & 一 & + & Absent & 一 & + & $\begin{array}{l}\text { Lateral and } \\
\text { down gaze } \\
\text { present }\end{array}$ \\
\hline 5 & H.B. & $3 \frac{1}{2} y r$ & $\mathbf{M}$ & $\begin{array}{l}\text { Haemophilus influenza } \\
\text { meningitis }\end{array}$ & 600 & + & Poor & - & - & $\begin{array}{l}\text { Lateral and } \\
\text { down gaze } \\
\text { present }\end{array}$ \\
\hline 6 & A.B. & $2 \mathrm{yr}$ & $\mathbf{M}$ & $\begin{array}{l}\text { Tuberculous menin- } \\
\text { gitis }\end{array}$ & 400 & + & $\begin{array}{l}\text { Spasm (eyes } \\
\text { maintained in } \\
\text { and down) }\end{array}$ & + & - & No response \\
\hline 7 & C.P. & $5 \mathrm{~d}$ & $\mathbf{F}$ & Aqueductal stenosis & - & + & $\begin{array}{l}\text { Not possible to } \\
\text { test }\end{array}$ & + & - & $\begin{array}{l}\text { Lateral gaze } \\
\text { present } \\
\text { bilaterally }\end{array}$ \\
\hline 8 & P.B. & $2 \mathrm{yr}$ & $\mathbf{M}$ & $\begin{array}{l}\text { Aqueductal stenosis } \\
\text { with shunt obstruc- } \\
\text { tion }\end{array}$ & - & + & Poor & - & + & $\begin{array}{l}\text { Lateral and } \\
\text { down gaze } \\
\text { present }\end{array}$ \\
\hline
\end{tabular}

* ICP: raised intracranial pressure. 
TABLE 2

VISUAL AND PNEUMOENCEPHALOGRAPHIC FINDINGS IN EIGHT PATIENTS

\begin{tabular}{|c|c|c|c|c|c|c|c|c|c|}
\hline No. & Name & Age & Sex & $\begin{array}{l}\text { Pupil } \\
\text { (mm) }\end{array}$ & Fundus & $\begin{array}{c}\text { Visual } \\
\text { function }\end{array}$ & $V E R^{*}$ & $O K N_{+}^{+}$ & Pneumoencephalogram \\
\hline 1 & L.F. & 7 wk & $\mathbf{F}$ & $\begin{array}{l}\text { 2. Both sides } \\
\text { L.R. poor } \dagger\end{array}$ & $\begin{array}{l}\text { Blurred disc } \\
\text { margins }\end{array}$ & $\begin{array}{l}\text { Does not fix } \\
\text { or follow }\end{array}$ & + & Absent & $\begin{array}{l}\text { Combined lumbar AEG and } \\
\text { ventriculogram revealed } \\
\text { large posterior fossa arach- } \\
\text { noid cyst; obstructive } \\
\text { hydrocephalus, due to ob- } \\
\text { struction, at rostral 4th } \\
\text { ventricle level }\end{array}$ \\
\hline 2 & M.E. & $5 \mathrm{~m}$ & $\mathbf{M}$ & $\begin{array}{l}\text { 5. Both sides } \\
\text { L.R. sluggish }\end{array}$ & $\begin{array}{l}\text { Blurred disc } \\
\text { margins }\end{array}$ & $\begin{array}{l}\text { Does not fix } \\
\text { or follow }\end{array}$ & + & Absent & $\begin{array}{l}\text { Lumbar AEG shows dilata- } \\
\text { tion of lateral, 3rd and 4th } \\
\text { ventricles with large } \\
\text { cisterna magna. Impression } \\
\text { was communicating hydro- } \\
\text { cephalus }\end{array}$ \\
\hline 3 & L.R. & $29 / 12$ a & $\mathbf{F}$ & $\begin{array}{l}\text { 5. Both sides } \\
\text { L.R. sluggish }\end{array}$ & $\begin{array}{l}\text { Absent } \\
\text { venous } \\
\text { pulsations }\end{array}$ & $\begin{array}{l}\text { Does not fix } \\
\text { or follow; } \\
\text { cortical } \\
\text { blindness? }\end{array}$ & $\begin{array}{l}\text { Photic driving } \\
\text { present }\end{array}$ & $\begin{array}{l}\text { Nystagmus } \\
\text { retractor- } \\
\text { ius on } \\
\text { downward } \\
\text { drum } \\
\text { rotation }\end{array}$ & $\begin{array}{l}\text { Ventriculogram revealed } \\
\text { aqueductal stenosis and } \\
\text { possibly also post-menin- } \\
\text { gitic communicating } \\
\text { hydrocephalus }\end{array}$ \\
\hline 4 & M.D. & $16 \mathrm{a}$ & $\mathbf{F}$ & $\begin{array}{l}\text { 5. Both sides } \\
\text { L.R. sluggish }\end{array}$ & $\begin{array}{c}\text { Bilateral } \\
\text { papill- } \\
\text { oedema }\end{array}$ & $\begin{array}{l}\text { Vacant stare; } \\
\text { cortical } \\
\text { blindness? }\end{array}$ & $\begin{array}{l}\text { Photic driving } \\
\text { present } \\
\text { (Fig. 1) }\end{array}$ & $\begin{array}{l}\text { Nystagmus } \\
\text { retrac- } \\
\text { torius on } \\
\text { downward } \\
\text { rotation } \\
\text { of drum }\end{array}$ & $\begin{array}{l}\text { Ventriculogram revealed } \\
\text { aqueductal stenosis }\end{array}$ \\
\hline 5 & H.B. & $3 \frac{1}{2} \mathrm{a}$ & $\mathbf{M}$ & $\begin{array}{l}\text { 4. Both sides } \\
\text { L.R. present }\end{array}$ & $\begin{array}{l}\text { Venous } \\
\text { pulsations } \\
\text { absent }\end{array}$ & $\begin{array}{l}\text { Does not fix } \\
\text { or follow }\end{array}$ & $\begin{array}{l}\text { Photic driving } \\
\text { present } \\
\text { (Fig. 2) }\end{array}$ & Absent & No air study done \\
\hline 6 & A.B. & $2 \mathbf{a}$ & $\mathbf{M}$ & $\begin{array}{l}\text { 2. Both sides } \\
\text { L.R. poor }\end{array}$ & $\begin{array}{l}\text { Absent } \\
\text { venous } \\
\text { pulsations } \\
\text { and hazy } \\
\text { disc mar- } \\
\text { gins }\end{array}$ & $\begin{array}{l}\text { Does not fix } \\
\text { or follow }\end{array}$ & $\begin{array}{l}\text { VER asym- } \\
\text { metrical. } \\
\text { Lower } \\
\text { amplitude } \\
\text { on left side }\end{array}$ & Absent & No air study done \\
\hline 7 & C.P. & $5 \mathrm{~d}$ & $\mathbf{F}$ & $\begin{array}{l}\text { 2. Both sides } \\
\text { L.R. present }\end{array}$ & $\begin{array}{l}\text { Pallor of } \\
\text { optic discs } \\
\text { bilaterally }\end{array}$ & $\begin{array}{l}\text { Does not fix } \\
\text { or follow }\end{array}$ & $\begin{array}{l}\text { VER not } \\
\text { done }\end{array}$ & Absent & $\begin{array}{l}\text { Ventriculogram revealed } \\
\text { aqueductal stenosis }\end{array}$ \\
\hline 8 & P.B. & $2 \mathrm{a}$ & $\mathbf{M}$ & $\begin{array}{l}\text { 5. Both sides } \\
\text { L.R. sluggish }\end{array}$ & $\begin{array}{l}\text { Venous en- } \\
\text { gorgement } \\
\text { present } \\
\text { with absent } \\
\text { pulsations }\end{array}$ & $\begin{array}{l}\text { Does not fix } \\
\text { or follow }\end{array}$ & + & $\begin{array}{l}\text { Poor re- } \\
\text { sponse on } \\
\text { lateral } \\
\text { rotation } \\
\text { and nystag- } \\
\text { mus re- } \\
\text { tractorius } \\
\text { on down- } \\
\text { ward drum } \\
\text { rotation }\end{array}$ & $\begin{array}{l}\text { Ventriculogram revealed } \\
\text { aqueductal stenosis }\end{array}$ \\
\hline
\end{tabular}

* VER: visual evoked response. $\quad$ †.R.: light reflex. $\quad$ OKN: opticokinetic nystagmus.

subject peers at the nose. One patient (case 2) has quick episodic divergence movements of the eyes followed by slow return to the neutral position. This patient could be considered to have divergence nystagmus, though exophoria resulting from momentary lack of fixation could not be ruled out completely. Cases 3,4 , and 8 exhibited all the characteristic features of the Sylvian aqueduct syndrome: paralysis of upward gaze, dilated poorly reacting pupils, and retraction nystagmus on attempted upward gaze.

The disorder of ocular movements was not explained by the reduced level of consciousness and poor cooperation on the part of these patients, a point which must be taken into consideration, since it is well known that obtunded and uncooperative patients have more difficulty in looking up than to the side or down.

Impairment of visual acuity was detected in all of these patients. Although the patients made no complaints of blindness, they did not appear to look at or recognize objects or faces and optokinetic nystagmus was absent or poor. However, some preservation of visual function was evi- 
denced by the presence of computer averaged visual evoked responses and photic driving of the EEG (Figs 1,2). This visual loss was also unrelated to the level of consciousness. Lorber (1967) had also reported temporary blindness in hydrocephalic children during a crisis of intracranial hypertension with complete recovery of visual function after shunting. This visual loss has been variously attributed to compression of the optic chiasma from the distended third ventricle (Dott, 1936), ischaemia of the occipital lobes from distortion of the posterior cerebral arteries (Lindenberg, 1955), and interstitial retrobulbar neuritis (Walsh and Hoyt, 1969). None of these hypotheses has been fully substantiated by pathological study. We suggest that the apparent 'blindness' may be primarily the consequence of paralysis of the reflexes of fixing and following, rather than impairment of visual sensory pathways per se; this is supported by the finding of preserved visual evoked responses. Myers (1964) observed similar visual behaviour in cats after stereotactic lesions in the superior colliculus, ventral periaqueductal grey matter, and the ventral tegmentum: 'These animals were sitting and staring straight ahead. The normal highly accurate movements of fixation and following were completely abolished, so that animals failed to move either head or eye to seek or follow objects of interest brought into view'. As similar visual behaviour was observed in our patients, one can speculate that dysfunction in superior colliculus, ventral tegmentum, and periaqueductal grey matter was probably responsible for this visual behaviour as well as paralysis of upward gaze and various abnormalities of convergence observed in these patients.

Of course the 'setting sun' ocular disturbance is a familiar accompaniment of hydrocephalus (Paine and Oppé, 1966; Ford, 1969; Matson, 1969). This refers to a downward turning of the eyes and retraction of upper lids (Collier's sign). The latter, when on a neurogenic basis, is considered to be due to a lesion of the posterior commissure (Collier, 1927). This, when combined with upward gaze palsy, would explain the pathogenesis of the 'setting sun' sign on the basis of periaqueductal dysfunction rather than the fanciful explanation of downward pressure of the expanded frontal lobes on the roof plates of the orbit (Ford, 1969; Matson, 1969).
Analysis of these patients revealed that the vertical gaze paralysis and the other ocular and visual disturbances were seemingly connected in some manner with the expansion of the ventricular system (pressure hydrocephalus), worsening as it progressed, lessening and finally disappearing as it was relieved by effective shunting. The disease which caused hydrocephalus and which varied from case to case was only indirectly responsible since it remained after the hydrocephalus was controlled. Cassinari et al. (1963), Walsh and Hoyt (1969), and recently Swash (1974) also postulated dilatation of the third ventricle and rostral aqueduct as the possible mechanism for upward gaze palsy observed in hydrocephalus. However, Lerner et al. (1969), Jerva and Nelson (1971), and recently Shallat et al. (1973) have postulated compression of the tectal and pretectal region from the distended suprapineal recess as the possible mechanism. The presence of other features of the Sylvian aqueduct syndrome along with upward gaze palsy in several of our cases would suggest periaqueductal dysfunction rather than the compression of the tectal region. It is also well known $\frac{\mathrm{\alpha}}{\mathrm{\alpha}}$ (Cogan, 1956) that in cases of pinealoma the paralysis of upward gaze disappears when shunt- 0 o ing relieves the hydrocephalus caused by theo tumour. Since the tumour was still there, the $\overrightarrow{0}$ direct compression of the tectal region from it $\stackrel{v}{\rightleftharpoons}$ could not have been responsible for the gaze palsy. Moreover, it is now known through the studies of Spiegel and Scala (1937), Christoff et al. (1960), Segarra and Ojeman (1961), and Nashold and Gills (1967) that the mechanism for vertical gaze is in the tegmentum of the upper mesencephalon and not in the superior collicular region.

If dilatation of the ventricular system causes these ocular and visual phenomena, one must inquire into its mechanism. The organization of all these functions is known to reside just anterior to the aqueduct of Sylvius and below the posterior part of the third ventricle. The centre of organization of downward gaze is caudal to that of the upward gaze. The susceptibility of these eye signs to hydrocephalic expansion varies but always seem to appear in an orderly fashion, upward gaze failing before the downward and the lateral gaze. The pupillary dilatation and the paralysis of the light reflex tend to occur when 
the hydrocephalus is advanced and at times when the level of consciousness is usually impaired. The depression of consciousness, seen in the full-blown hydrocephalic syndrome, may result from compression of the midbrain reticular system as the dysfunction extends beyond the immediate periaqueductal region. One might postulate a gradient of force from the expanding aqueduct and the third ventricle which must diminish from the ependyma outwards and differentially stretch and compress the neuronal fibre systems at varying distances from the ventricle and aqueduct. A nice point in the pathophysiology of ventricular dilatation is raised from a more practical side: the ocular disorders may be numbered among the more delicate manifestations of hydrocephalic paralysis of cerebral function.

Swash (1974) suggested that these ocular abnormalities were more likely to occur in hydrocephalus due to aqueductal stenosis than in the communicating variety. Most of our cases did have aqueductal stenosis; however, our case 2 , with no evidence of aqueductal stenosis, still developed all these ocular abnormalities. We tend to believe that it is the acuteness and severity of the hydrocephalus rather than the site of block which is the determining factor. Lack of these ocular abnormalities in adult-onset communicating hydrocephalus is not surprising, since most of these cases have normal or low cerebrospinal fluid pressure (Hakim and Adams, 1965).

Finally, it should be remembered that upward gaze palsy and the other ocular, pupillary, and visual disturbances described in our patients have proved to be valuable indices of raised intracranial pressure, particularly in cases where high pressure in the ventricular system is not reflected in the lumbar subarachnoid space (case 3 ). The eye signs should always be looked for when a child with a shunt becomes drowsy or apathetic, disinterested in food, or nauseated, or if older children complain of headache or unsteadiness of gait. If the ocular signs appear rapidly, they signal a crisis of intracranial hypertension that demands urgent surgical intervention. At the same time their recognized occurrence in conjunction with a diversity of diseases of variable anatomical topography deprives them of localizing value, with reference to the causative disease. They belong, in the language of Collier (1904), to a large group of 'false localizing signs' in neurology.

The authors are grateful to Dr Raymond D. Adams and Dr David G. Cogan for their kind criticism and suggestions and to Mrs Pamela Picariello for secretarial assistance.

\section{REFERENCES}

Beckett, R. S., Netsky, M. G., and Zimmerman, H. M. (1950). Developmental stenosis of the aqueduct of Sylvius. American Journal of Pathology, 26, 755-787.

Cassinari, V., Pagni, C. A., and Vitale, A. (1963). Sindrome di Parinaud in corso di idrocefalo cronico iperteso: sofferenza della regione mesencefalica da dilatazione della porzione posteriore del III ventricolo? Minerva Neurochirurgica, 7, 84-88.

Christoff, N., Anderson, P. J., and Bender, M. B. (1960). Convergence and retractory nystagmus. Transactions of the American Neurological Association, 85, 29-32.

Cogan, D. G. (1956). Neurology of the Ocular Muscles, pp. 123 and 126. Thomas: Springfield, Ill.

Collier, J. (1904). The false localising signs of intracranial tumour. Brain, 27, 490-508.

Collier, J. (1927). Nuclear ophthalmoplegia, with especial reference to retraction of the lids and ptosis and to lesions of the posterior commissure. Brain, 50, 488-498.

Dott, N. (1936). Bitemporal hemianopia. British Medical Journal, 2, 296.

Fisher, C. M. (1967). Some neuro-ophthalmological observations. Journal of Neurology, Neurosurgery, and Psychiatry, 30, 383-392.

Ford, F. R. (1969). Diseases of the Nervous System in Infancy, Childhood and Adolescence, 5th edn, p. 75. Thomas: Springfield, Ill.

Fredericks, E. J., and Van Nuis, C. (1967). Diverticulum of the rostral cerebral aqueduct with ocular dysfunctions. Archives of Neurology, 16, 32-36.

Globus, J. H., and Bergman, P. (1946). Atresia and stenosis of the aqueduct of Sylvius. Journal of Neuropathology and Experimental Neurology, 5, 342-363.

Hakim, S., and Adams, R. D. (1965). The special clinical problem of symptomatic hydrocephalus with normal cerebrospinal fluid pressure. Journal of the Neurological Sciences, 2, 307-327.

Hatcher, M. A., Jr, and Klintworth, G. K. (1966). The sylvian aqueduct syndrome. A clinicopathologic study. Archives of Neurology, 15, 215-222.

Holmes, G. (1921). Palsies of the conjugate ocular movements. British Journal of Ophthalmology, 5, 241-271.

Jerva, M. J., and Nelson, R. (1971). Parinaud's syndrome in progressive hydrocephalus. Mercy Medical Journal, 1, 19-20.

Kestenbaum, A. (1946). Clinical Methods of Neuro-ophthalmologic Examination, p. 255. Grune and Stratton: New York.

Lerner, M. A., Kosary, I. Z., and Cohen, B. E. (1969). Parinaud's syndrome in aqueduct stenosis: its mechanism and ventriculographic features. British Journal of Radiology, 42, 310-312.

Lindenberg, R. (1955). Compression of brain arteries as pathogenic factor for tissue necroses and their areas of predilection. Journal of Neuropathology and Experimental Neurology, 14, 223-243.

Lorber, J. (1967). Recovery of vision following prolonged blindness in children with hydrocephalus or following pyogenic meningitis. Clinical Pediatrics, 6, 699-703. 
Matson, D. D. (1969). Neurosurgery of Infancy and Childhood, 2nd edn, p. 211. Thomas: Springfield, Ill.

Myers, R. E. (1964). Visual deficits after lesions of brain stem tegmentum in cats. Archives of Neurology, 11, 73-90.

Nag, T. K., and Falconer, M. A. (1966). Non-tumoral stenosis of the aqueduct in adults. British Medical Journal, 2, 1168-1170.

Nashold, B. S., Jr, and Gills, J. P., Jr (1967). Ocular signs from brain stimulation and lesions. Archives of Ophthalmology (Chic.), 77, 609-618.

Paine, R. S., Oppé, T. E. (1966). Neurological Examination of Children. Clinics in Developmental Medicine, p. 111. Heinemann: Lonaion.

Pennybacker, J. (1940). Stenosis of the aqueduct of Sylvius. Proceedings of the Royal Society of Medicine, 33, 507-512.

Schwarz, G. A., and Rosner, A. A. (1941). Displacement and herniation of the hippocampal gyrus through the incisura tentorii. A clinicopathologic study. Archives of Neurology and Psychiatry, 46, 297-321.
Segarra, J. M., and Ojeman, R. J. (1961). Convergence nystagmus. Neurology (Minneap.), 11, 883-893.

Shallat, R. F., Pawl, R. P., and Jerva, M. J. (1973). Significance of upward gaze palsy (Parinaud's syndrome) in hydrocephalus due to shunt malfunction. Journal of Neurosurgery, 38, 717-721.

Smith, J. L., Zieper, I., Gay, A. J., and Cogan, D. G. (1959). Nystagmus retractorius. Archives of Ophthalmology, 62 , 864-867.

Spiegel, E. A., and Scala, N. P. (1937). Ocular disturbances associated with experimental lesions of the mesencephalic central gray matter, with special reference to vertical ocular movements. Archives of Ophthalmology, 18, 614-632.

Swash, M. (1974). Periaqueductal dysfunction (the Sylvian aqueduct syndrome): a sign of hydrocephalus? Journal of Neurology, Neurosurgery, and Psychiatry, 37, 21-26.

Walsh, F. B., and Hoyt, W. F. (1969). Clinical Neuroophthalmology, 3rd edn, vol. 1, pp. 228, 305; and vol. 2, p. 1408. Williams and Wilkins: Baltimore. 